\title{
Analisis Menurunnya Produksi Udara Bertekanan Yang Dihasilkan Oleh Air Compressor di Kapal SPOB. CINTIANA PRATAMA
}

\author{
Hariyadi ${ }^{1}$ Paris J.M. Senda ${ }^{2)}$ Tasdik Tona ${ }^{3)}$ \\ Polieteknik IImu Pelayaran Makassar \\ Jalan Tentara Pelajar no. 173 Makassar, Kode Pos 90172 \\ Telp.(0411) 3616975; Fax(0411) 36288732 \\ E-mail:pipmks@pipmakassar.com
}

\begin{abstract}
ABSTRAK
Kompresor mempunyai peranan yang sangat penting di atas kapal dalam menunjang pengoperasian kapal. Dalam pengoperasiannya kompresor sering mengalami gangguan yang menyebabkan menurunnya produksi udara pada kompresor udara. Penelitian ini dilaksanakan di atas kapal SPOB. Cintiana Pratama Milik perusahaan PT. Cindara Pratama Lines selama satu tahun sumber data diperoleh langsung dengan metode observasi, kepustakaan dan dokumen yang berkaitan. Kesimpulan dalam penelitian ini adalah terjadinya kerusakan pada ring piston akibat adanya partikel lain yang terhisap bersama udara sehingga terbentuk kerak pada katup tekanan rendah dan tekanan tinggi dan terjadinya kebocoran pada sistim perpipaan akibat kurangnya pemeliharaan yang Menyebabkan Menurunnya produksi udara bertekanan pada kompresor.
\end{abstract}

Kata Kunci : Kompresor, Tekanan, Produksi udara

\section{PENDAhUluAN}

Pada era globalisasi ini perkembangan teknologi telah merambah seluruh aspek kehidupan manusia, hal ini menunjukkan bahwa kehidupan manusia lebih kompetitif, sehingga kita lebih dituntut untuk dapat memberikan hasil yang terbaik, demikian pada dalam dunia pelayaran yang bergerak dalam jasa angkutan laut.

Perusahaan pelayaran merupakan salah satu stake holder di dalam sistem transportasi laut yang memberikan jasa pelayaran yang mempunyai tujuan untuk mendistribusikan muatan dari suatu pelabuhan ke pelabuhan tujuan dengan aman, selamat, ekonomis dan tepat waktu. Transportasi laut akan berhasil jika diimbangi dengan adanya armada 
pelayaran yang tangguh, serta tenaga pelaut yang handal, professional, terampil dan bertanggung jawab dibidangnya masing-masing.

Untuk menunjang kelancaran pelayaran di laut khususnya di dalam berlayar, kelengkapan kapal sangat perlu untuk diperhatikan seperti halnya untuk menunjang pengoperasian mesin kapal diantaranya kompresor udara yang digunakan untuk keperluan starting main engine dan keperluan lain di atas kapal. Tetapi pada kenyataanya sering terjadi gangguan pada elemen kompresor yang dapat mempengaruhi olah gerak kapal. Oleh sebab itu, dibutuhkan kompresor yang dapat memenuhi kebutuhan udara yang bertekanan di atas kapal, untuk mengoptimalkan kinerja dari kompresor udara sehingga dibutuhkan perawatan yang baik secara terus menerus guna menunjang kelancaran pada saat olah gerak kapal.

Berdasarkan dari uraian di atas, penulis membuat rumusan masalah yaitu: "Apa penyebab menurunnya produksi udara bertekanan pada air compressor di atas kapal".

\section{TINJAUAN PUSTAKA}

Menurut Maanen, Motor Diesel Kapal Jilid I (1986:12.1), Kompressor merupakan salah satu komponen dari sistem udara kerja diatas kapal yang berkaitan untuk menyelenggarakan olah gerak kapal yang lancar. Dengan kompressor yang berfungsi baik, maka kesiapan akan tersedianya udara dalam botol angin akan terjamin sehingga setiap saat dapat mengantisipasi kebutuhan olah gerak.

Prinsip kerja kompressor udara torak yaitu:

1. Langkah Isap

a. Pada waktu torak berada di Titik Mati Atas (TMA), katub buang dan katup isap dalam keadaan tertutup, kemudian pada waktu torak mulai bergerak dari Titik Mati Atas (TMA) ke Titik Mati Bawah (TMB) katub isap akan membuka.

b. Selama gerakan torak dari Titik Mati Atas (TMA) ke awal langkah isap, udara yang ada di dalam silinder dan ber-ekspansi, tetapi 
udara sebenarnya baru siap masuk kedalam silinder setelah tekanan di dalam silinder tersebut turun mencapai tekanan penguapan. Oleh karena itu, selama gerakan dari akhir proses pembuangan ke awal langkah isap, tidak terjadi pengisapan (langkah bebas).

c. Setelah torak mencapai awal langkah isap dan meneruskan gerakannya menuju Titik Mati Bawah (TMB), mulai diisap masuk ke dalam silinder. Pada waktu torak berada di Tititk Mati Bawah, katub isap menutup dan proses pengisapan udara selesai.

2. Langkah Kompresi

a. Pada waktu torak berada di Titik Mati Bawah (TMB), baik katup isap maupun katup buang ada dalam keadaan menutup.

b. Selanjutnya, selama gerakan torak dari Titik Mati Bawah (TMB) ke langkah pembuangan gas di dalam silinder mengalami proses kompresi, sehingga tekanan gas akan naik secara berangsurangsur.

c. Apabila telah dicapai tekanan buang, katub buang mulai membuka sehingga udara akan keluar dari dalam silinder.

\section{Langkah Keluar}

Selama gerakan dari tekanan buang Titik Mati Atas (TMA), pengeluaran udara berlangsung pada tekanan konstan. Proses kompresi selesai pada waktu torak barada di Titik Mati Atas (TMA). Dengan demikian udara ditekan keluar dan kemudian masuk ke dalam bejana udara tetapi sebelumnya udara didinginkan oleh pendingin udara tekanan tinggi.

Pada dasarnya kompressor torak mempunyai bagian-bagian komponen utama yaitu :

1. Torak

Torak berfungsi untuk mengisap dan menekan udara di dalam silinder. 
2. Batang hubung (batang penggerak)

Batang hubung juga dibuat dari baja tempa. Kedua ujung batang hubung mempunyai bantalan, yang satu yang berhubungan dengan poros engkol dan lainnya berhubungan dengan pena torak.

3. Poros engkol

Poros engkol dibuat dari baja tempa. Bagian-bagian dari poros yang bersinggungan dengan bantalan diperiksa dengan cara induksi.

4. Silinder

Silinder merupakan suatu bejana kedap udara di mana di dalamnya terdapat torak yang bergerak bolak-balik untuk menghisap dan menekan udara.

5. Ruang engkol

Merupakan komponen penting dan harus menopang bantalan utama poros engkol dengan kokoh serta berfungsi untuk menampung minyak yang bersirkulasi di dalam kompressor

6. Katup

Terdiri dari katup isap dan katub tekan yang dipergunakan pada kompressor dapat membuka dan menutup sendiri diakibatkan karena adanya perbedaaan tekanan yang terjadi antara bagian dalam dan luar silinder.

7. Roda daya

Fungsi roda daya yang utama adalah untuk meratakan putaran poros engkol.

\section{METODE PENELITIAN}

Penelitian ini dilakukan di atas kapal SPOB.CINTIANA PRATAMA selama 12 bulan. Pengumpulan data yang akan dilakukan adalah sebagai berikut: 
1. Metode observasi (survey)

Metode ini dilakukan dengan cara melakukan pengamatan dan pengambilan data secara langsung di lapangan.

2. Metode penelitian pustaka (library research)

Pengumpulan data ini dilakukan dengan cara studi pustaka, yaitu mengumpulkan literatur-literatur yang berkaitan dengan permasalahan yang dialami oleh penulis melalui buku-buku serta artikel-artikel yang didapat pada saat melaksanakan praktek maupun sewaktu di bangku perkuliahan.

Untuk menunjang kelengkapan pembahasan, dilakukan dua jenis pengambilan data, yaitu :

a. Data Primer

Data ini diperoleh dari hasil pengamatan secara langsung di atas kapal dengan cara melakukan pengamatan, pengukuran dan pencatatan di lokasi.

b. Data Sekunder

Data sekunder adalah data yang diperoleh dari referensireferensi dan bahan perkuliahan yang berhubungan dengan permasalahan yang akan dibahas.

Metode analisis menggunakan metode deskriptif yaitu tulisan yang berisikan paparan dan uraian mengenai suatu objek permasalahan yang timbul.

\section{HASIL PENELITIAN DAN PEMBAHASAN}

Kompresor udara adalah salah satu pesawat bantu yang ada di atas kapal dan mempunyai peranan yang sangat penting untuk menghasilkan udara yang bertekanan, dan berfungsi sebagai udara penjalan pada saat start awal mesin induk maupun mesin diesel penggerak generator, serta digunakan sebagai penggerak peralatan pneomatik, pengisi tangki-tangki hydrosfor dan sebagai pembersih. Kompresor dalam pengoprasiannya sering mengalami gangguan yang 
menyebabkan kompresor tidak bekerja dengan optimal. Sehingga produksi udara yang dihasilkan menurun. Diantara gangguan tersebut adalah terjadinya kebocoran pada ring piston, tidak berfungsinya katup isap, katup tekanan rendah dan tekanan tinggi dengan baik serta terjadinya kebocoran pada sistim pemipaan yang terdapat pada kompresor sehingga udara yang dihasilkan tidak sempurna. Sedangkan efisiensi dan kerugian pada kompresor adalah perbandingan antara hasil (output), dengan pemasukan (input). Pada kompresor terdapat beberapa efisiensi:

1. Efisiensi volumetris.

2. Efisiensi kompresi

3. Efisiensi mekanis

4. Efisiensi keseluruhan

Adapun faktor-faktor yang dapat menyebabkan terjadinya penurunan udara bertekanan yang dihasilkan oleh kompresor udara adalah kerusakan pada ring piston, tidak berfungsinya katup isap katup tekanan rendah dan tekanan tinggi dengan baik serta adahnya kebocoran pada sistim pemipaan yang terdapat pada kompresor.

\section{A. Identifikasi Masalah}

Pada kejadian di atas kapal SPOB. CINTIANA PRATAMA, dilakukan perbaikan karena terjadi kerusakan pada piston dan ring piston dimana piston tidak dapat bergerak. Pada saat pembongkaran ditemukan banyak nya tumpukan kerak pada dinding silinder, pemukaan piston, katup tekanan tinggi, dan katup tekanan rendah. Hal ini disebabkan oleh beberapa faktor sebagai berikut :

1. Kerusakan pada ring piston

Beberapa faktordapat menyebabkan kerusakan pada ring piston:

a. Kurangnya Pelumasan

Ada beberapa faktor yang menyebabkan kurangnya pelumasan pada ring piston antara lain kurangnya minyak 
lumas dalam karter, tersumbatnya saringan minyak lumas, dan Pelumasan yang tidak sesuai.

b. Adanya goresan pada ring piston

Apabila pada cincin torak terdapat goresan, ini akan mengakibatkan udara akan lolos ke bagian bawah piston yaitu carter, ini sangat mempengaruhi kerja atau fungsi kompresor

c. Faktor Usia

Kerusakan pada ring piston dapat dipengaruhi oleh faktor usia sehingga lama kelamaan akan aus, sebab komponen ini lama kerja maksimum pada 6000 jam.

2. Tidak normalnya kinerja katup

Penulis menganalisa pada katup tersebut terdapat banyak terak-terak yang melekat pada bagian katup sehingga katup tidak bekerja secara optimal, dimana pada katup ini pada saat terjadinya langkah isap tidak membuka dengan baik karena adanya terak yang menahan pegas tersebut.

3. Kebocoran pada sistim pemipaan udara

Kebocoran pada sistem pemipaan udara dapat menimbulkan kerugian yang mana dalam hal ini kebocoran udara bertekanan mengakibatkan berkurangnya produksi udara yang dihasilkan oleh kompresor disamping itu memperpanjang waktu operasi kompresor untuk menaikkan tekanan udara yang diinginkan. Kebocoran yang terjadi pada sistim pemipaan udara bertekanan yakni pada titik lengkungan pipa tembaga antara tingkat tekanan rendah dan tingkat tekanan tinggi. 


\section{B. Pembahasan Masalah}

Cara mengatasi penyebab menurunnya tekanan udara yang dihasilkan oleh kompresor adalah sebagai berikut :

1. Kerusakan pada ring piston

Ada beberapa faktor yang menyebabkan terjadinya kerusakan pada ring piston dan cara mengatasi masalah tersebut:

a. Kurangnya Pelumasan

Maka perlu dilakukan penanganan pada masalah tersebut yaitu dengan cara mengover houle kompresor dan mengganti ring piston yang sudah aus. Serta menambahkan minyak lumas pada carter.

b. Adanya Goresan Pada Ring Piston

Adapun tindakan yang harus diambil:

1) Menjaga kebersihan blower pengisapan ke kamar mesin.

2) Kebersihan disekitar kompresor harus selalu dijaga.

3) Selalu memperhatikan kondisi dari saringan kompresor.

4) Selalu memperhatikan kondisi dari saringan minyak lumas.

c. Faktor Usia

Caranya adalah dengan menggantinya dengan ring yang baru, sedangkan pemasangan ring piston harus membentuk sudut $120^{\circ}$ atau sesuai dengan intruction manual book. Ring piston diganti pada setiap 6000 jam kerja.

2. Tidak normalnya kinerja katup

Pada waktu melakukan overhoul katub-katub ini akan dibersihkan dari terak-terak yang melekat dan kering pada katub, setelah itu dibongkar atau dibuka dengan melonggarkan baut pada katub (set bolt) dari dudukan (seat) 
tengah. Setelah selesai katub direndam dengan solar (HSD) untuk membersihkan satu persatu pada bagian-bagian dari plat katup tersebut.

3. Kebocoran pada sistim pemipaan udara

Penanganan kebocoran pada pipa tembaga antar tingkat tekanan rendah dengan tingkat tekanan tinggi dapat dilakukan:

a. Pastikan kompresor dalam keadaan "off" dalam artian kompresor tidak terhubung dengan arus listrik.

b. Menutup katup pada sistim pemipaan kompresor dan memastikan tidak ada tekanan di dalam kompresor.

c. Membuka pipa yang bocor dari sistim kompresor dengan melepas baut pengikat sambungan pada kedua ujung pipa.

d. Melakukan pengelasan pada pipa bocor dengan menggunakan las acetelin.

e. Setelah pengelasan pada pipa dilakukan pengetesan sebelum dipasang pada kompresor.

f. Pipa yang telah dilas kemudian dipasang kembali dengan mengganti packing dengan yang baru dan kompresor siap untuk uji coba.

\section{PENUTUP}

\section{A. Kesimpulan}

1. Terjadinya kebocoran pada ring piston disebabkan oleh kurang optimalnya pelumasan pada kompresor type $\mathrm{H}-64$ yang selama ini menggunakan minyak lumas MEDITRAN S.A.E 40, tidak sesuai maka harus diganti dengan minyak lumas multi grade S.A.E $15 \mathrm{~W}-40$ yang mampu bekerja pada suhu $20^{\circ} \mathrm{C}$ sampai $100^{\circ} \mathrm{C}$. agar pelumasan selalu optimal dan tidak menyebabkan keausan pada bagian-bagian kompresor.

2. Adanya partikel padat yang terisap bersama udara sehingga menyebabkan produksi udara menurun. 
3. Menurunnya prduksi udara pada kompresor dapat dipengaruhi oleh faktor usia atau lamanya jam kerja komponen-komponen kompresor.

4. Terbentuknya kerak pada katup yang terbawa oleh aliran udara sehingga dapat mempengaruhi kerja dari pegas serta menimbulkan kemacetan pada katup.

5. Adanya kebocoran pada sistim pemipaan pada kompresor yang disebabkan kuranya pemeliharaan pada sistim tersebut.

\section{B. Saran}

1. Gunakan minyak lumas sesuai dengan kebutuhan kompresor, dengan memperhatikan viskositas minyak lumas maka kerusakan dapat diperkecil.

2. Bersihkan daerah sekitar kompresor setiap saat agar udara yang diisap oleh kompresor tidak mengandung kotoran dan debu, maupun benda-benda keras seperti keramik dan pasir. Serta perawatan yang rutin terhadap saringan udara agar selalu berfungsi dengan baik.

3. Perhatikan jam kerja dari ring piston dan komponenkomponen kompresor lainnya.

4. Perhatikan perawatan pada setiap katup, baik katup isap maupun katup tekan, karena pada kedua katup ini sangat berpengaruh bila tidak bekerja dengan baik karena banyaknya kotoran kerak yang sudah kering dan melekat pada katup. Bersihkan katup tersebut dan periksa kebocoran pada katup.

5. Perhatikan pemeliharaan terhadap sistim pemipaan yang terdapat pada kompresor. 


\section{DAFTAR PUSTAKA}

[1]. Maanen. (1986). Motor Diesel Kapal. Jakarta: Erlangga.

[2]. Sularso \& Haruo, T. (2004). Pompa dan Kompresor. Pemilihan, Pemakaian, dan Pemeliharaan. Jakarta: PT. Pradnya Paramita.

[3]. Sutjiatmo \& Indera, N. (1981). Kompresor I. Departemen Pendidikan dan Kebudayaan Direktorat Pendidikan Menengah Kejuruan.

[4]. UNEP, Kompresor dan Sistem Sistem Udara Tekan, Pedoman Effesiensi Untuk Industri di Asia (online 19:15 25 oktober 2019), www.energyeffesiensyasia.org

[5]. PIP-MKS. (2012), Pedoman Penulisan Skripsi. Makassar: Tim PIPmks.

[6]. Syawaluddin syawal (2017), Mesin Teknolgi. Teknologi Terkini (online 20.2025 oktober 2019) www.teknologiterkini.org 